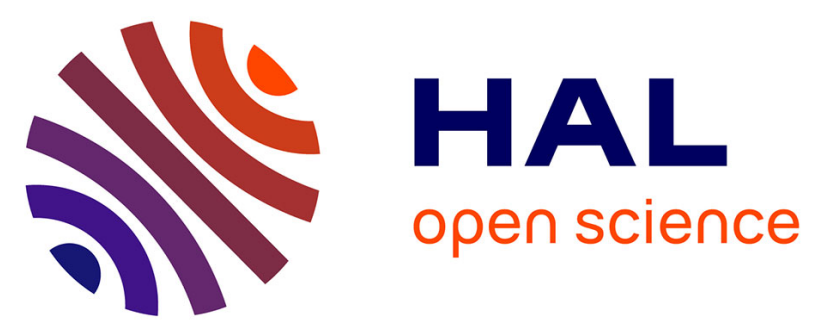

\title{
Alteration of pathogenicity-linked life-history traits by resistance of its host Solanum tuberosum impacts sexual reproduction of the plant pathogenic oomycete Phytophthora infestans.
}

J. A. J. Clément, Julie a J Clément, Hélène Magalon, R. Pellé, B. Marquer, Didier Andrivon

\section{To cite this version:}

J. A. J. Clément, Julie a J Clément, Hélène Magalon, R. Pellé, B. Marquer, et al.. Alteration of pathogenicity-linked life-history traits by resistance of its host Solanum tuberosum impacts sexual reproduction of the plant pathogenic oomycete Phytophthora infestans.. Journal of Evolutionary Biology, 2010, 23 (12), pp.2668-76. 10.1111/j.1420-9101.2010.02150.x . hal-00941636

\author{
HAL Id: hal-00941636 \\ https://hal.science/hal-00941636
}

Submitted on 4 May 2016

HAL is a multi-disciplinary open access archive for the deposit and dissemination of scientific research documents, whether they are published or not. The documents may come from teaching and research institutions in France or abroad, or from public or private research centers.
L'archive ouverte pluridisciplinaire HAL, est destinée au dépôt et à la diffusion de documents scientifiques de niveau recherche, publiés ou non, émanant des établissements d'enseignement et de recherche français ou étrangers, des laboratoires publics ou privés. 


\title{
Alteration of pathogenicity-linked life-history traits by resistance of its host Solanum tuberosum impacts sexual reproduction of the plant pathogenic oomycete Phytophthora infestans
}

\author{
J. A. J. CLÉMENT*, H. MAGALON*, R. PELLÉ†, B. MARQUER* \& D. ANDRIVON* \\ *INRA, Agrocampus Ouest, University of Rennes 1, UMR 1099, Biology of Organisms e Populations Applied to Plant Protection BiO3P, Le Rheu, France \\ $\dagger I N R A$ UMR 118 APBV, Ploudaniel, France
}

\begin{abstract}
Although sexual reproduction implies a cost, it represents an evolutionary advantage for the adaptation and survival of facultative sexual pathogens. Understanding the maintenance of sex in pathogens requires to analyse how host resistance will impact their sexual reproduction through the alteration of their life-history traits. We explored this experimentally using potato (Solanum tuberosum) and one of its pathogens, the heterothallic oomycete Phytophthora infestans. Sexual reproduction was highest on hosts favouring asexual multiplication of the pathogen, suggesting similar nutritional requirements for both sexual and asexual sporulation. Sexual reproduction was also highest on hosts decreasing the latent period, probably because of a trade-off between growth and reproduction. Distinguishing host effects on each pathogenic trait remains however uneasy, as most life-history traits linked to pathogenicity were not independent of each other. We argue that sexual reproduction of $P$. infestans is an adaptation to survive when the host is susceptible and rapidly destroyed.
\end{abstract}

\section{Introduction}

Since the introduction of the Red Queen Hypothesis (Van Valen, 1973), the postulate that sexual reproduction is maintained in hosts by parasitic pressure has been investigated in many empirical and theoretical studies (see Clay \& Kover, 1996 for the specific case of plantpathogen systems; Salathe et al., 2008 for a wide-ranging review). Conversely, the increasing interest in understanding how pathogens adapt to their hosts stimulated some experimental and theoretical work to better understand the effect of hosts on the development and the maintenance of sex in their pathogens (Gemmill et al., 1997; Howard \& Lively, 2002; Zhan et al., 2007). For pathogens multiplying mainly asexually, the conservation of sex, even when it is not mandatory to complete the life cycle, can be advantageous. New combinations of parental alleles generated by sexual reproduction can

Correspondence: Julie A. J. Clément, INRA, Agrocampus Ouest, University of Rennes 1, UMR 1099, Biology of Organisms \& Populations Applied to Plant Protection BiO3P, F-35653 Le Rheu, France.

Tel.: 3302234858 19; fax: 3302234851 50;

e-mail: julie.clement@rennes.inra.fr indeed lead to increased genotypic diversity (Burdon \& Silk, 1997) and sometimes to increased pathogenic fitness (Grigg et al., 2001; Klarfeld et al., 2009). Furthermore, intragenic recombinations occurring during the meiosis can also generate new alleles and provide new pathogenic phenotypes and/or host specificities (Yang $\delta$ Gabriel, 1995). Finally, sexual reproduction often results in the formation of resting organs, which allow pathogens to cope with unfavourable environmental conditions. Thus, sexual reproduction can facilitate the adaptation of the pathogen to its abiotic environment but also to its hosts (Zhan et al., 2007; Michod et al., 2008).

Biotrophic and hemibiotrophic plant pathogens (i.e. pathogens infecting living host tissue) have only a relatively short time window to infect, grow and reproduce asexually and/or sexually before the host dies (i.e. natural or pathogen induced mortality). With limited resources, the strategy of such pathogens is to optimize host exploitation by allocating the energy pumped from the host into either growth or reproduction (Kozlowski, 1992; Perrin \& Sibly, 1993). When both asexual and sexual reproductions are possible, the switch between 
both reproductive modes is determined largely by the availability of resources (Chamberlain \& Ingram, 1997) and by the presence of compatible sexual partners in species with separate sexes. Depending on host features, particularly host resistance, the time window for resource exploitation could be very variable in length, so the growth-reproduction allocation strategy of the pathogen can also be affected.

Two types of plant resistance have been described by Van der Plank (1968). The first is qualitative resistance (also called total resistance), usually based on gene-forgene interactions that result in a hypersensitivity response and thus in an absence of disease when the pathogen is avirulent (i.e. lack of the virulence allele corresponding to the host resistance allele). The second is quantitative (partial resistance), allowing the pathogen to infect and multiply but limiting its spread (e.g. its development, growth and/or reproduction). Partial resistance is thus the only one to affect the length of the time window the pathogen has to reproduce. Two methods are most commonly used to assess the level of partial resistance of a host. The first is to score disease severity progress on whole plants over an entire growing season (i.e. polycyclic epidemics) and to compare it between cultivars. This method therefore assesses the cumulative effect of various resistance components over several reproduction cycles of the pathogen (Parlevliet, 1979). The second method is to precisely measure each resistance component in biotests under controlled conditions, during an epidemic monocycle. In this case, each test aims to identify which life-history traits of the pathogen are altered and how much. These life-history traits can thus be regarded as either components of pathogenicity or components of host resistance. Both methods provide complementary information. Determining how host resistance features (playing on pathogen life-history traits) could affect sexual reproduction of the pathogen is of great interest for understanding the maintenance of sex in pathogens and the adaptation to their hosts. Although some studies aimed to link host global resistance levels with pathogen sexual reproduction (Hanson \& Shattock, 1998; Cowger et al., 2002), none has addressed this issue so far by regarding host resistance as alterations of pathogen life-history traits. There are also very few data on how the resource allocation strategy of the pathogen can be affected by the host effect on pathogen life history.

The Solanum tuberosum-Phytophthora infestans plant pathogen system is a suitable model to answer these questions. Different levels of partial resistance to $P$. infestans exist among potato (S. tuberosum) cultivars (Hodgson, 1962). Phytophthora infestans (the causal agent of potato and tomato late blight) is a hemibiotrophic oomycete causing severe yield and quality losses (Robertson, 1991). Its life cycle begins with the penetration of host tissue by germ tubes from sporangia (or zoospores differentiated within the sporangia), followed by mycelial growth and formation of new sporangia resulting from clonal (asexual) reproduction. Different life-history traits, such as latent period (LP), lesion growth rate (LGR) and sporangia production, can be assessed in miniature biotests performed in controlled conditions on detached potato leaflets (Lebreton et al., 1999), making host resistance components accessible measures. As P. infestans is a heterothallic species (i.e. requires the presence of thalli of opposite mating types to achieve sexual reproduction; Robertson, 1991), the occurrence of sexual reproduction can be controlled by putting compatible isolates (referred to as Al and A2) into contact or not (Gallegly \& Galindo, 1958). The formation of sexual organs is induced by hormonal exchanges and results in the production of oospores (Ko, 2007). Oospores are thick-walled resting organs that can survive for extended periods in the soil in the absence of the host and can serve as primary soil-borne inoculum for at least 2-3 years (Andersson et al., 1998). They are reported to cause infections early in the growing season (Lehtinen \& Hannukkala, 2004; Hannukkala et al., 2007; Widmark et al., 2007) and may result in the development of invasive genotypes with higher adaptive potential. Because of these economical and epidemiological consequences, the ecological and environmental conditions leading to oospore formation are receiving increasing attention.

Because $P$. infestans is closely dependent on its host for sexual and asexual reproduction, determining whether (and how) host resistance is linked to oospore production is a key issue in this respect. Some studies have attempted to link the level of partial resistance to the amount of oospores produced, but no consensus results stand out (Drenth et al., 1995; Hanson \& Shattock, 1998; Hammi et al., 2001; Stromberg et al., 2001). A common feature to all these studies is that resistance levels were assessed as field scores, which, as indicated earlier, can mask different combinations of resistance components integrated over the course of an entire epidemic. Therefore, these experiments do not allow one to adequately investigate which pathogen life-history traits, when altered by host resistance, will impact oospore production.

Here, we thus explored relations between host individual resistance components and pathogen sexual reproduction in the experimental settings. Because resistance components are defined as life-history traits of the pathogen modulated by the host, they provide a functional understanding of the host effect on the pathogen.

\section{Materials and methods}

\section{Isolates of Phytophthora infestans}

Phytophthora infestans is a spore-producing filamentous oomycete. Although it is a hemibiotrophic pathogen in 
nature, it is able to grow on artificial media (Ribeiro, 1978). Moreover, it is a heterothallic species with two mating types (Gallegly \& Galindo, 1958) named Al and A2. Four Al and two A2 mating type isolates from the laboratory collection, maintained on $15 \%$ pea agar medium, were chosen based on variability for three pathogenicity traits (sporangia production, lesion area and LP) assessed on the susceptible potato cultivar Bintje in a former experiment (C. Pasco \& R. Corbière, unpublished data). All isolates were isolated in 2005 or 2006 and were sampled in the two major French areas of potato production (North and Brittany). They were collected from different cultivars (Bintje or KaptahVandel), but French populations of $P$. infestans have been shown to be weakly differentiated and to be adapted to Bintje (Montarry et al., 2008).

\section{Plant material}

Nine cultivars - Bintje (B), Désirée (D), Furore (F), Herbstrote $(\mathrm{H})$, Möwe (M), Noorstar (N), Robijn (Rb), Roode Industrie (Ri), and Rosafolia (Rs) - were chosen for displaying differences in levels and components of partial resistance according to previous tests performed by Corbiere et al. (2002). Because potato is vegetatively propagated, each cultivar corresponds to a unique genotype. These cultivars were bred in the 1900-1930s, before the introduction and widespread use of Solanum demissum race-specific resistance $\mathrm{R}$-genes in potato breeding programs, so that only partial resistance was present. Among them, Bintje is a reference susceptible to P. infestans commonly used in the laboratory.

All nine cultivars were tested for field resistance at the INRA breeding station of Ploudaniel (western Brittany, France), where the disease pressure is always high. For each cultivar, two plots of two plants were scored once a week for disease progress on foliage. Plots were laid out in a two-block randomized field trial. Every second row, plants of the highly susceptible cultivar Bintje were planted to ensure that each tested plant received the same inoculum pressure. Weekly disease scores allowed us to calculate the relative area under disease progress curves (see rAUDPC in Table 1), which reflect the level of partial resistance (Andrivon et al., 2006). The whole experiment was performed in two consecutive years (2008 and 2009). Results of the year 2009 are not shown but provided the same ranking of cultivars.

All cultivars were also multiplied at the INRA station of Ploudaniel in separated plots, and tubers were used to produce the plants for the remaining experiments. These plants were grown in 12 -cm-diameter pots, in a glasshouse maintained at a minimum of $18{ }^{\circ} \mathrm{C}$, under natural light supplemented with sodium lamps for a 16-h photoperiod. They were fertirrigated weekly with a 7:12:40 N:P:K fertilizer solution. For detached leaf tests, leaflets similar in size were picked from fully expanded leaves from the median area of 6-to 8-week-old plants. They were transferred to the laboratory in watertight boxes to prevent drying before inoculation.

\section{Inoculum preparation}

Maintaining isolates on agar media for extended periods can alter their pathogenicity. However, pathogenicity can be restored by re-infecting host tissue (Jinks \& Grindle, 1963). Each isolate was thus multiplied separately once on potato leaves of the susceptible cultivar Bintje before starting the experiments. To this end, suspensions of sporangia were prepared by flooding 3- to 4-week-old cultures on Petri dishes in $5 \mathrm{~mL}$ of deionised sterile water (DSW). Suspensions were kept at $4{ }^{\circ} \mathrm{C}$ for approximately 2-3 h to promote zoospore release. Leaflets of $\mathrm{cv}$. Bintje from 6- to 8-week-old plants, placed on the lids of inverted Petri dishes containing water agar to obtain near

Table 1 Characterization of the nine host cultivars from field measures performed at the Breeding station of Ploudaniel (Finistère, France) and from biotests measures performed during the experiment on six isolates of Phytophthora infestans.

\begin{tabular}{|c|c|c|c|c|c|c|c|}
\hline \multirow{3}{*}{$\frac{\text { Hosts }}{\text { Bintje }}$} & \multirow{3}{*}{$\begin{array}{l}\text { Field measures } \\
\text { rAUDPC } \\
0.50\end{array}$} & \multicolumn{6}{|c|}{ Biotest measures } \\
\hline & & \multicolumn{2}{|c|}{$\begin{array}{l}\text { SPR (sporangia day }{ }^{-1} \\
\text { of sporulation) }\end{array}$} & \multicolumn{2}{|c|}{$\begin{array}{l}\text { LGR }\left(\mathrm{cm}^{2} \text { day }^{-1} \text { of }\right. \\
\text { growth) }\end{array}$} & \multicolumn{2}{|l|}{ LP (days) } \\
\hline & & 37515 & $\mathrm{a}$ & 2.44 & $a b$ & 3.31 & $\mathrm{a}$ \\
\hline Desiree & 0.43 & 14783 & $b$ & 2.24 & $a b$ & 3.36 & $\mathrm{a}$ \\
\hline Furore & 0.43 & 16048 & $b$ & 2.61 & $\mathrm{a}$ & 3.83 & $b$ \\
\hline Möwe & 0.15 & 15088 & $\mathrm{~b}$ & 2.27 & $a b$ & 4.66 & $\mathrm{C}$ \\
\hline Noorstar & 0.46 & 15904 & $b$ & 2.33 & $a b$ & 3.86 & $\mathrm{~b}$ \\
\hline Robijn & 0.14 & 7705 & bc & 2.17 & $a b$ & 3.64 & $a b$ \\
\hline Roode Industrie & 0.32 & 10253 & $\mathrm{~b}$ & 2.05 & $\mathrm{~b}$ & 3.94 & $b$ \\
\hline Rosafolia & 0.30 & 11785 & $b$ & 1.49 & $\mathrm{C}$ & 3.56 & $a b$ \\
\hline
\end{tabular}

Same letter in a column means no significant difference between means $(\alpha=0.05)$.

rAUDPC, relative area under disease progress curves; SPR, the sporangia production rate; LGR, the sporulating lesion growth rate; LP, the latent period. 
$100 \%$ relative humidity, were inoculated by depositing droplets containing about 1000 sporangia each. After 8 days incubation under controlled conditions $\left(18-15^{\circ} \mathrm{C}\right.$ day/night temperature, $16 \mathrm{~h}$ daylight), newly formed sporangia were washed from leaflets in $10 \mathrm{~mL}$ DSW. The concentration of the resulting suspensions was adjusted to $5.10^{4}$ sporangia $\mathrm{mL}^{-1}$ using a haemocytometer.

\section{Diversity of resistance components over the range of hosts}

Each isolate was inoculated separately onto six detached leaflets of each cultivar (six isolates $\times$ nine cultivars $\times$ six replicates) by depositing a $20 \mu \mathrm{L}$ droplet containing about 1000 sporangia on the centre of each leaflet. Before inoculation, leaflets were placed as pairs onto the lids of Petri dishes containing water agar, as described earlier. Petri dishes containing inoculated leaflets were kept in clear boxes and stored in a climate chamber regulated at 18-15 ${ }^{\circ} \mathrm{C}$ (day/night temperature, $16 \mathrm{~h}$ daylight).

Three life-history traits of the pathogen (also used as resistance components) were measured. After inoculation, leaflets were observed daily under a magnifying glass to check the appearance of sporangia, allowing us to assess the latent period (LP) (time between inoculation and first sporulation; in days). Six days after inoculation, leaflets were placed under a magnifying glass fitted with a digital camera, and the sporulating surface was contoured and analysed with the ARCHIMED ${ }^{\circledR}$ software (Microvision Instruments, Evry, France) to obtain the sporulating lesion area. Immediately thereafter, sporangia were washed from leaflets in $10 \mathrm{~mL}$ Isoton II (saline buffer; Beckman Coulter, Villepinte, France) and counted with a Coulter Z2 counter (Beckman Coulter).

The sporulating lesion growth rate (LGR) was calculated by dividing the lesion area measured 6 days postinoculation by the number of days since the onset of sporulation (i.e. the sporulation period calculated as $6-$ LP). The LGR was assumed to be constant over time for each leaflet. The sporangia production rate (SPR) was calculated by dividing the total number of sporangia by the sporulation period.

\section{Sexual reproduction}

In vitro fertility was checked first by pairing compatible isolates (i.e. the eight $\mathrm{Al} / \mathrm{A} 2$ pairs) on pea agar in Petri dishes (Shaw et al., 1985). Oospore formation in all pairs was observed under a binocular microscope after incubation at $18{ }^{\circ} \mathrm{C}$ for $12-14$ days, indicating that all pairs are fertile.

Each of the eight compatible pairs were then inoculated onto 12 leaflets of each of the nine potato cultivars by depositing a droplet containing about 500 sporangia per isolate (allowing infection), for a total of 1000 sporangia per leaflet. Suspensions were prepared separately for each isolate. Droplets from the respective suspensions were deposited either next to each other onto the centre of the leaflet [the 'distance $0 \mathrm{~mm}$ (dist$0)^{\prime}$ inoculation], allowing almost immediate contact between parental isolates, or about $30 \mathrm{~mm}$ apart [the 'distance $30 \mathrm{~mm}$ (dist-30)' inoculation] implying mycelial growth before contact between parents (eight pairs $\times$ nine cultivars $\times$ two distances of inoculation $\times$ six replicates). As described for the previous experiment, leaflets were placed in pairs onto the lids of Petri dishes containing water agar, and Petri dishes were kept after inoculation in clear boxes and incubated in a climate chamber settled at $18-15^{\circ} \mathrm{C}$ (day/night temperature, 16 h daylight).

Fifteen days after inoculation, leaflets were dipped for $2-4 \mathrm{~h}$ in $\mathrm{NaClO}$ and then ground in $500 \mu \mathrm{L}$ DSW by shaking for several minutes in a $2-\mathrm{mL}$ tube containing small glass beads. Oospores were counted in $1 \mathrm{~mm}^{3}$ of the homogenized suspension with a haemocytometer.

\section{Statistical analyses}

All statistical analyses were performed using the general statistical software package RGUI version 2.10.0 (R Development Core Team, 2005).

In all analyses, including pairing leaflets in the model as pseudoreplications did not improve the fit of the model according to the Akaike Information Criterion. They were thus removed from all models presented below.

Because the aim of this work was to analyse the role of host resistance, isolates and isolate $\times$ cultivar interactions were included as random factors into the statistical mixed models. The host cultivar effect was considered as a fixed factor and was tested for each resistance component. Before analysis, SPR was $\log 10$-transformed to ensure the normality of residuals.

Multiple comparisons of means were carried out using the Tukey honest significant differences test, because intervals were based on the range of the sample means (Crawley, 2007). Tukey HSD function was applied to the most parsimonious models explaining variation of each resistance component with the host cultivar as a factor.

To test whether correlations between traits were significant and whether correlation parameters between resistance components depended on the host, variation in (log10-transformed) SPR was analysed by means of ANCOVA, with either LP or LGR as a covariate and host cultivar as the factor. In the same way, variation in LGR was analysed with LP as covariate and host cultivar as factor.

Generalized linear models (GLM) were adjusted to the data for analyses related to the sexual reproduction. The proportion of leaflets where no sexual reproduction was detected was tested using GLM with the binomial error distribution; host cultivars and pair identities were included as explanatory variables. The amount of oospores produced when sexual reproduction was detected was tested using GLM with a Gamma error distribution; 
distance of inoculation and host were the explanatory variables. The significance of the explanatory variables was tested with a $\chi^{2}$ test by adding terms in the analyses of variance (ANOVA) sequentially. The cor.test function was also used to assess and to test the significance of the correlation coefficient between sexual reproduction and each life-history trait.

\section{Results}

\section{Diversity of resistance components over the range of hosts tested}

All but one of the 324 inoculations (nine cultivars $\times$ six isolates $\times$ six leaflets) performed to assess foliar components of host resistance gave a sporulating lesion allowing us to measure the three resistance components (LP, LGR and SPR).

LGR varied from $1.49 \pm 0.11$ (SE) in Rosafolia to $2.61 \pm 0.08 \mathrm{~cm}^{2} \mathrm{day}^{-1}$ in Furore. LP ranged from $3.31 \pm 0.08$ days for Bintje to $4.66 \pm 0.11$ days for Möwe, which corresponds, respectively, to the low and high level of host resistance measured in the field (rAUDPC). The lowest SPR was observed in Herbstrote $\left(5781 \pm 713\right.$ sporangia day $\left.{ }^{-1}\right)$, almost seven times less than the highest one as observed in Bintje $\left(37515 \pm 3270\right.$ sporangia day $\left.{ }^{-1}\right)$. The percentage of variation because of the isolate $\times$ host interaction was always lower than between isolates variation and than residual variance, which reflects variation within isolates (Table 2). At least one host cultivar differed significantly from the others for each of the three resistance components (LP, LGR and SPR: $P<0.001$ for all, Table 2 ). Differences between mean values are shown in Table 1, where letters (from ' $a$ ' to ' $c$ ') correspond to an increasing level of host resistance.

Table 2 Analysis of variance and random effects from the minimal mixed models fitted to results for each of the host resistance components; lme function of the nlme package of $\mathrm{R}$ software was used for the mixed model.

\begin{tabular}{|c|c|c|c|}
\hline & SPR & LGR & LP \\
\hline \multicolumn{4}{|l|}{ ANOVA of the mixed model } \\
\hline \multicolumn{4}{|l|}{ Host effect } \\
\hline$F_{9,40}$ & 156.12 & 40.59 & 96.68 \\
\hline$P$-value & $<0.0001$ & $<0.0001$ & $<0.0001$ \\
\hline \multicolumn{4}{|l|}{ Random effects } \\
\hline Between isolates & 0.067 (39\%) & $0.080(20 \%)$ & $0.105(31 \%)$ \\
\hline $\begin{array}{l}\text { Interaction term: } \\
\text { isolates } \times \text { genotypes }\end{array}$ & $0.023(14 \%)$ & $0.050(12 \%)$ & $0.031(9 \%)$ \\
\hline Residuals & $0.080(47 \%)$ & $0.282(68 \%)$ & $0.205(60 \%)$ \\
\hline
\end{tabular}

Random effects are presented as the estimated variance from the minimal model and percentage of total variance is calculated into brackets.

SPR, the sporangia production rate (sporangia day ${ }^{-1}$ of sporulation); LGR, the sporulating lesion growth rate $\left(\mathrm{cm}^{2} \mathrm{day}^{-1}\right.$ of growth); LP, the latent period (days).
Each cultivar had a unique combination of resistance components (Table 1). Furthermore, several patterns of resistance components could be associated to nearly the same rAUDPC, i.e. the same level of field resistance. For instance, although Möwe and Herbstrote displayed a comparable rAUDPC (0.15 and 0.11 , respectively), the resistance in Möwe was mainly because of a significantly longer LP $(4.66 \pm 0.11$ days for Möwe vs. $3.58 \pm$ 0.11 days for Herbstrote), whereas that of Herbstrote resulted from a much lower SPR (5781 \pm 713 for Herbstrote vs. $15088 \pm 1860$ sporangia day $^{-1}$ for Möwe).

SPR (log10-transformed) was positively correlated to LGR $\left(r=0.39, P<0.0001\right.$; host effect: $F_{8,305}=12.44$, $P<0.0001 ;$ LGR $\times$ host effect interaction: $F_{8,305}=1.84$, $P=0.07)$ and negatively correlated to LP $(r=-0.28$, $P<0.0001$; host effect: $F_{8,305}=16.42, \quad P<0.0001$; LP $\times$ host effect interaction: $\left.F_{8,305}=0.63, P=0.76\right)$. No evidence of correlation $(r=0.09, P=0.11)$ was detected between LGR and LP.

\section{Sexual reproduction}

Two of the 864 leaflets inoculated to assess sexual reproduction of the eight pathogen pairs on the nine hosts gave no sporulating lesions, and were thus excluded from further analyses. Oospores were detected on 839 of 862 remaining leaflets. Oospore detection differed between hosts $\left(\chi_{8}^{2}=26.36, P=0.001\right)$ and between the isolates pairs $\left(\chi_{7}^{2}=30.53, \quad P<0.0001\right)$. Indeed, 18 of the 23 leaflets with lesions but no oospores were from the three most resistant hosts (nine for Möwe, five for Roode Industrie and four for Herbstrote).

For leaflets where oospores were observed, the distance of inoculation had a significant effect $\left(\chi_{1}^{2}=44.95\right.$, $P<0.0001)$ on the numbers of oospores produced. Indeed, increasing the distance between the two sexual partners led to a decrease in oospore production, but the magnitude of this decrease depended on the host cultivar (host effect: $\chi_{8}^{2}=208.45, P<0.0001$; interaction host $\times$ distance: $\chi_{8}^{2}=17.42, P=0.001$; Fig. 1).

No effect of LGR on oospore production was observed (Fig. 2, $r=0.02, P=0.96)$. By contrast, oospore production increased linearly with SPR $(r=0.87, P<0.01$; Fig. 2) and decreased on hosts that caused a longer LP, although the correlation was not statistically significant $(r=-0.48, P=0.19$; Fig. 2).

\section{Discussion}

\section{Sexual reproduction of the pathogen and resistance components of the host}

Sexual reproduction of $P$. infestans was linked to host effects on LP and on SPR, but not on LGR (Fig. 2). More precisely, we observed a strong correlation between host effect on SPR and oospore production (Fig. 2). This correlation could be because of host characteristics that 


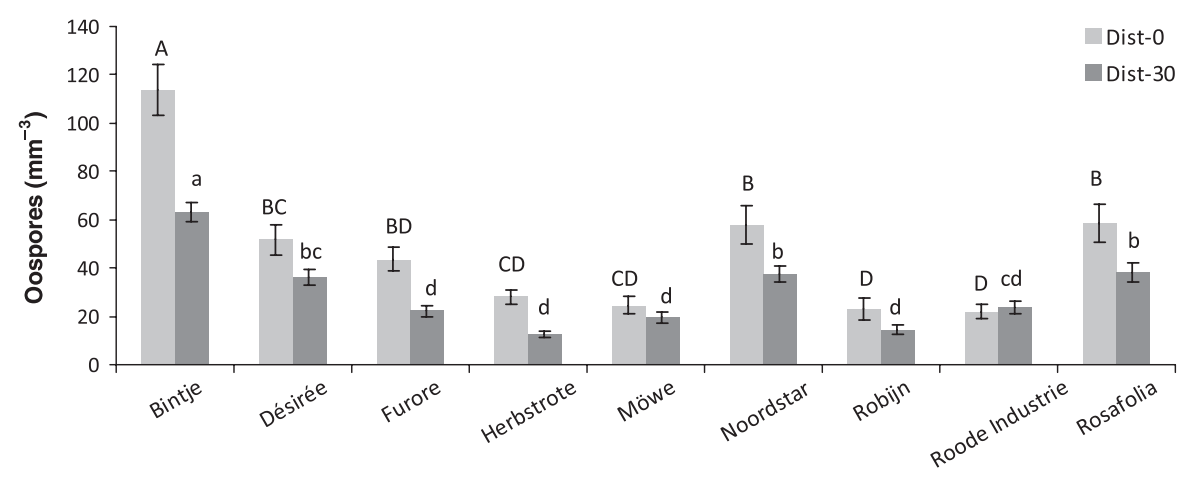

Fig. 1 Means of oospore production for each host genotype and for the two distances of inoculation. Capital letters correspond to multiple comparisons for the inoculation at null distance (dist-0), and small letters correspond to multiple comparisons for the inoculation at $30 \mathrm{~mm}$ (dist-30). Among capital letters (or small letters), the same letter above the bar corresponds to nonsignificant difference of means. Error bars correspond to standard error.
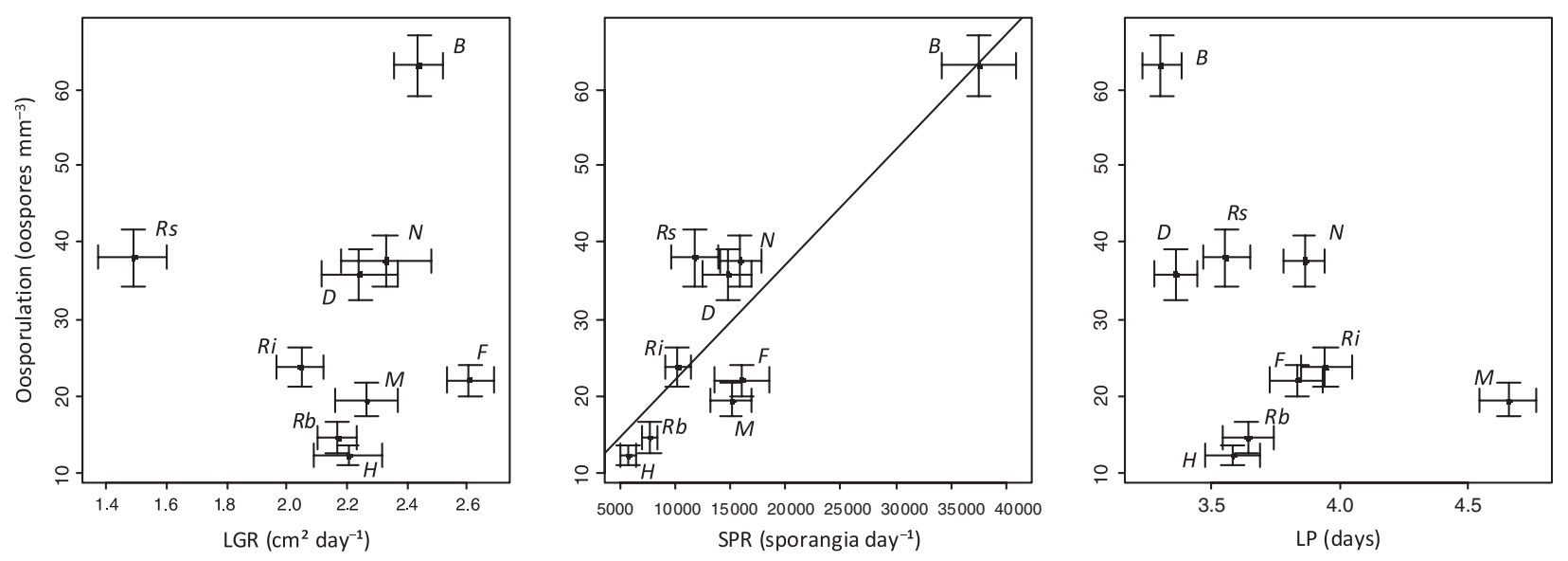

Fig. 2 Correlations between oospore production and values of resistance components (LGR, lesion growth rate; SPR, sporangia production rate; LP, latent period) for each host genotype and for the dist-30 inoculation. Each point corresponds to mean value for a given host cultivar. Letters near each point correspond to abbreviation given for each cultivar (B, Bintje; D, Désirée; F, Furore; H, Herbstrote; M, Möwe; N, Noorstar; Rb, Robijn; Ri, Roode Industrie; and Rs, Rosafolia). Horizontal bars correspond to standard error of the $\times$ values calculated for the six isolates. Vertical bars correspond to standard error of the oospore production calculated on the eight pairs of isolates. Within the plot SPR, coefficients of the line are from linear model performed between means of oospores and means of sporangia production.

influence the ecology of the pathogen. For example, the ability of the pathogen to exploit host tissue to form reproduction structures (sporangia and oospores) could be linked to the nutritive quality of the host tissue. Indeed, partial resistance possibly results from differences in the chemical contents of plant tissue, e.g. sugars (Daniele et al., 2003) that are known to be used by the pathogen during sporulation (Judelson et al., 2009). This hypothesis is supported by the fact that the same isolates produce different amounts of sporangia and oospores according to the artificial media they are grown on (Medina \& Platt, 1999). The same authors also found that the levels of both asexual and sexual sporulation were highest for the same medium, suggesting similar requirements for the production of both types of spores.
Sexual reproduction appears lower on hosts that increased the LP even though statistical results proved only a tendency. A likely explanation is based on the unavoidable trade-off between growth and reproduction when resources are limited (Kozlowski, 1992; Perrin \& Sibly, 1993). During the LP, mycelium starts to grow within the host. When sporangia production is delayed (longer LP), the resources absorbed from the host are used exclusively for mycelial growth and are thus not available anymore when asexual reproduction starts. This could explain the trade-off between sporangia production and LP as well as the negative impact of LP on oospore production. An assessment of mycelial density or weight would be needed to confirm this hypothesis. Unfortunately, this was not an experimentally 
accessible variable at the time of the experiment. Moreover, it is not necessarily tightly correlated with an accessible one (such as the LGR), because mycelium growth rate is not clearly related to mycelium biomass in axenic cultures (J.A.J. Clément, personal observations). In the same way, when parental isolates were inoculated at a distance of $30 \mathrm{~mm}$, oospore production was lower than at a null distance. Before the meeting between both sexual partners, isolates had to grow and for the same reason as for LP, lower amounts of oospores were produced. Another explanation, compatible with the previous one, is that the host effect could be similar on the time from inoculation to asexual reproduction (asexual LP) and to sexual reproduction (sexual LP). Observations made by Hanson \& Shattock (1998) supported the hypothesis that oospore production could be delayed depending on host resistance. Nevertheless, no data in the literature indicated a similar host effect on both asexual and sexual LP.

Whether oospore production is linked to one or more resistance components is difficult to evaluate. Resistance components correspond to pathogen life-history traits, which are affected by the host. Finding correlations between traits is not surprising, and they were observed for several plant/pathogen systems (Pariaud et al., 2009). We found that sporangia production was positively correlated to LGR and negatively to LP. This latter correlation implies a trade-off between sporangia production and LP, and the ANCOVA results indicate that the trade-off slope is equal for all hosts. Thus, it is difficult to conclude whether variation in oospores production is causally linked to LP or seems to be so because of the trade-off between LP and sporangia production (and vice versa). However, outlier points in Fig. 2 [Herbstrote $(\mathrm{H})$ and Robijn $(\mathrm{Rb})]$ correspond to cultivars having a strong negative effect on SPR. This strongly suggests that each resistance component is directly involved in the resulting variation of oospore production and does not act only as side effects of trade-offs.

\section{Implications for adaptation and maintenance of sexual reproduction in Phytophthora infestans}

Higher oospore production was found in the more susceptible hosts, i.e. in hosts which led to higher sporangia production, shorter LP and higher rAUDPC (see Fig. 2 and Table 1). This is consistent with observations by Hanson $\&$ Shattock (1998) during their first experiment, but not with all other experiments performed on this pathosystem (Drenth et al., 1995; Hammi et al., 2001; Stromberg et al., 2001). Our results are also consistent with data obtained in another heterothallic plant pathogen, the ascomycete Mycosphaerella graminicola (Cowger et al., 2002).

Whether the larger amount of oospores recorded on more susceptible hosts results from an independent adaptation process is unclear. Sexual progenies from one parent sampled on potato and the other on tomato showed a host preference, potato or tomato (Knapova et al., 2002). Sexual reproduction could thus lead to host specialization. Montarry et al. (2008) showed that French $P$. infestans isolates are adapted to the most abundant host (cv. Bintje) for pathogenicity. Therefore, sexual reproduction could either be a pleiotropic effect of adaptation for pathogenicity or result from an independent selection process. Population genetics analyses indicate that sexual reproduction of $P$. infestans seems to occur in France under natural conditions (H. Magalon, personal communication), but the fitness of oospore progenies on the most frequent host cultivar has not been experimentally tested yet. However, sexual reproduction could generate genotypic and phenotypic diversity leading to either increased or decreased pathogenicity and ability to bypass major resistance genes (Klarfeld et al., 2009), although most progeny isolates tend to be less pathogenic than parental strains (Mayton et al., 2000). It is noteworthy that all these studies showed a very low in vitro germination rate, which could introduce a bias in the assessment of the progeny compared to the parental features.

A process as costly as sexual reproduction would not represent an evolutionary advantage if offspring fitness is low. Nevertheless, processes in the pathogen's life history which prevent it from becoming too virulent also allow the preservation of the host, thus allowing the pathogen to persist too, as stated by the trade-off hypothesis between transmission and virulence (Alizon et al., 2009). This is especially true for (hemi-) biotrophic pathogens as $P$. infestans, whose survival depends on its host presence. Moreover, all the sexual progenies tested in many studies on $P$. infestans showed ability to overwinter in field conditions (Andersson et al., 1998; Mayton et al., 2000; Turkensteen et al., 2000). Producing more oospores on susceptible, rapidly destroyed host cultivars could be an adaptation to survive in the absence of the host.

Our study was the first to focus on how life-history traits of the pathogen affected by host resistance, rather than an aggregate measure of partial resistance in the field, explain the variation in sexual reproduction. How host resources are exploited and how host tissue composition impacts on the pathogen strategy is a worthy issue for future investigations, both for breeding applications as well as for understanding the adaptive processes of $P$. infestans to race nonspecific resistance. In all cases, determining whether the positive correlation between sexual and asexual reproductions result from independent but convergent selection or from pleiotropic effects of pathogenicity-linked life-history traits remains to be elucidated.

\section{Acknowledgments}

We thank J.E. Chauvin (UMR APBV, INRA Rennes) for help in the choice of host cultivars, R. Corbière and 
C. Pasco for providing P. infestans isolates, Frederic Hamelin for helpful comments on measurements of life-history traits and Yannick Outreman for his help with statistical analyses. This research was part of the projects 'Invasion and persistence of plant pathogens' funded by INRA and BBSRC, EMERFUNDIS (Agence Nationale de la Recherche grant 07-BDIV-003) and BIOExploit (EU integrated project FOOD-CT-2005513959).

\section{References}

Alizon, S., Hurford, A., Mideo, N. \& Van Baalen, M. 2009. Virulence evolution and the trade-off hypothesis: history, current state of affairs and the future. J. Evol. Biol. 22: 245259.

Andersson, B., Sandstrom, M. \& Stromberg, A. 1998. Indications of soilborne inoculum of Phytophthora infestans. Potato Res. 41: 305-310.

Andrivon, D., Pelle, R. \& Ellisseche, D. 2006. Assessing resistance types and levels to epidemic diseases from the analysis of disease progress curves: principles and application to potato late blight. Am. J. Potato Res. 83: 455-461.

Burdon, J.J. \& Silk, J. 1997. Sources and patterns of diversity in plant-pathogenic fungi. Phytopathology 87: 664-669.

Chamberlain, M. \& Ingram, D.S. 1997. The balance and interplay between asexual and sexual reproduction in fungi. In: Advances in Botanical Research Incorporating Advances in Plant Pathology, Vol. 24, pp. 71-87. Academic Press Ltd, London.

Clay, K. \& Kover, P.X. 1996. The Red Queen Hypothesis and plant/pathogen interactions. Annu. Rev. Phytopathol. 34: 29-50.

Corbiere, R., Trémoulu, B., Lucas, J.M., Pelle, R., Ellisseche, D. \& Andrivon, D. 2002. Components of partial resistance to late blight in ancient potato cultivars. Fifteenth Triennial Conference of EAPR, Hamburg, Germany.

Cowger, C., McDonald, B.A. \& Mundt, C.C. 2002. Frequency of sexual reproduction by Mycosphaerella graminicola on partially resistant wheat cultivars. Phytopathology 92: 1175-1181.

Crawley, M. 2007. The $R$ Book. John Wiley $\&$ Sons Ltd., Chichester.

Daniele, E., Dommes, J. \& Hausman, J.F. 2003. Carbohydrates and resistance to Phytophthora infestans in potato plants. Acta Physiol. Plant. 25: 171-178.

Drenth, A., Janssen, E.M. \& Govers, F. 1995. Formation and survival of oospores of Phytophthora infestans under natural conditions. Plant Pathology 44: 86-94.

Gallegly, M.E. \& Galindo, J. 1958. Mating types and oospores of Phytophthora infestans in nature in Mexico. Phytopathology 48: 274-277.

Gemmill, A.W., Viney, M.E. \& Read, A.F. 1997. Host immune status determines sexuality in a parasitic nematode. Evolution 51: 393-401.

Grigg, M.E., Bonnefoy, S., Hehl, A.B., Suzuki, Y. \& Boothroyd, J.C. 2001. Success and virulence in toxoplasma as the result of sexual recombination between two distinct ancestries. Science 294: 161-165.

Hammi, A., Bennani, A., El Ismaili, A., Msatef, Y. \& Serrhini, M.N. 2001. Production and germination of oospores of Phytophthora infestans (Mont.) de Bary in Morocco. Eur. J. Plant Pathol. 107: 553-556.
Hannukkala, A.O., Kaukoranta, T., Lehtinen, A. \& Rahkonen, A. 2007. Late-blight epidemics on potato in Finland, 1933-2002; increased and earlier occurrence of epidemics associated with climate change and lack of rotation. Plant Pathol. 56: 167-176.

Hanson, K. \& Shattock, R.C. 1998. Formation of oospores of Phytophthora infestans in cultivars of potato with different levels of race nonspecific resistance. Plant Pathol. 47: 123-129.

Hodgson, W.A. 1962. Studies of the nature of partial resistance in the potato to Phytophthora infestans. Am. Potato J. 39: 813.

Howard, R.S. \& Lively, C.M. 2002. The Ratchet and the Red Queen: the maintenance of sex in parasites. J. Evol. Biol. 15: 648-656.

Jinks, J.L. \& Grindle, M. 1963. Changes induced by training in Phytophthora infestans. Heredity 18: 245-264.

Judelson, H.S., Tani, S. \& Narayan, R.D. 2009. Metabolic adaptation of Phytophthora infestans during growth on leaves, tubers and artificial media. Mol. Plant Pathol. 10: 843-855.

Klarfeld, S., Rubin, A. \& Cohen, Y. 2009. Pathogenic fitness of oosporic progeny isolates of Phytophthora infestans on lateblight-resistant tomato lines. Plant Dis. 93: 947-953.

Knapova, G., Schlenzig, A. \& Gisi, U. 2002. Crosses between isolates of Phytophthora infestans from potato and tomato and characterization of F-1 and F-2 progeny for phenotypic and molecular markers. Plant Pathol. 51: 698-709.

Ko, W.H. 2007. Hormonal regulation of sexual reproduction in Phytophthora. Bot. Stud. 48: 365-375.

Kozlowski, J. 1992. Optimal allocation of resources to growth and reproduction - implications for age and size at maturity. Trends Ecol. Evol. 7: 15-19.

Lebreton, L., Lucas, J.M. \& Andrivon, D. 1999. Aggressiveness and competitive fitness of Phytophthora infestans isolates collected from potato and tomato in France. Phytopathology 89: 679-686.

Lehtinen, A. \& Hannukkala, A. 2004. Oospores of Phytophthora infestans in soil provide an important new source of primary inoculum in Finland. Agric. Food Sci. 13: 399-410.

Mayton, H., Smart, C.D., Moravec, B.C., Mizubuti, E.S.G., Muldoon, A.E. \& Fry, W.E. 2000. Oospore survival and pathogenicity of single oospore recombinant progeny from a cross involving US-17 and US-8 genotypes of Phytophthora infestans. Plant Dis. 84: 1190-1196.

Medina, M.V. \& Platt, H.W. 1999. Comparison of different culture media on the mycelial growth, sporangia and oospore production of Phytophthora infestans. Am. J. Potato Res. 76: 121125.

Michod, R.E., Bernstein, H. \& Nedelcu, A.M. 2008. Adaptive value of sex in microbial pathogens. Infect. Genet. Evol. 8: 267-285.

Montarry, J., Glais, I., Corbiere, R. \& Andrivon, D. 2008. Adaptation to the most abundant host genotype in an agricultural plant-pathogen system - potato late blight. J. Evol. Biol. 21: 1397-1407.

Pariaud, B., Ravigne, V., Halkett, F., Goyeau, H., Carlier, J. \& Lannou, C. 2009. Aggressiveness and its role in the adaptation of plant pathogens. Plant Pathol. 58: 409-424.

Parlevliet, J.E. 1979. Components of resistance that reduce the rate of epidemic development. Annu. Rev. Phytopathol. 17: 203222.

Perrin, N. \& Sibly, R.M. 1993. Dynamic-models of energy allocation and investment. Annu. Rev. Ecol. Syst. 24: 379-410.

R Development Core Team 2005. R: A Language and Environment for Statistical Computing. Vienna. 
Ribeiro, O.K. 1978. A Source Book of the Genus Phytophthora. J. Cramer, Vaduz.

Robertson, N.F. 1991. The Challenge of Phytophthora infestans. In: Phytophthora infestans, the Cause of Late Blight of Potato, Vol. 7 (D.S. Ingram \& P.H. Williams, eds), pp. 1-30. Academic press, London.

Salathe, M., Kouyos, R.D. \& Bonhoeffer, S. 2008. The state of affairs in the kingdom of the Red Queen. Trends Ecol. Evol. 23: 439-445.

Shaw, D.S., Fyfe, A.M., Hibberd, P.G. \& Abdelsattar, M.A. 1985. Occurrence of the rare A2 mating type of Phytophthora infestans on imported Egyptian potatoes and the production of sexual progeny with Al mating types from the UK. Plant Pathol. 34: 552-556.

Stromberg, A., Bostrom, U. \& Hallenberg, N. 2001. Oospore germination and formation by the late blight pathogen Phytophthora infestans in vitro and under field conditions. J. Phytopathol. 149: 659-664.

Turkensteen, L.J., Flier, W.G., Wanningen, R. \& Mulder, A. 2000. Production, survival and infectivity of oospores of Phytophthora infestans. Plant Pathol. 49: 688-696.
Van Valen, L. 1973. A new evolutionary law. Evol. Theory 1 $1-30$.

VanderPlank, J.E. 1968. Disease Resistance in Plants. Academic Press, New York.

Widmark, A.K., Andersson, B., Cassel-Lundhagen, A., Sandstrom, M. \& Yuen, J.E. 2007. Phytophthora infestans in a single field in southwest Sweden early in spring: symptoms, spatial distribution and genotypic variation. Plant Pathol. 56: 573-579.

Yang, Y.O. \& Gabriel, D.W. 1995. Intragenic recombination of a single plant pathogen gene provides a mechanism for the evolution of new host specificities. J. Bacteriol. 177: 49634968.

Zhan, J., Mundt, C.C. \& McDonald, B.A. 2007. Sexual reproduction facilitates the adaptation of parasites to antagonistic host environments: evidence from empirical study in the wheat-Mycosphaerella graminicola system. Int. J. Parasitol. 37: 861-870. 